\section{Estimation of Outcrossing in Basil}

\author{
Renee G. Nation, Jules Janick, and James E. Simon ${ }^{1}$ \\ Department of Horticulture, Purdue University, West Lafayette, \\ IN 47907-1165
}

\section{Additional index words. Ocimum basilicum, Ocimum kilimandscharicum, Lamiaceae, herbs, breeding}

\begin{abstract}
The rate of outcrossing in basil [eight accessions of Ocimum basilicum L. and one accession purported to be $O$. kilimandscharicum Guerke ('Juicy Fruit')] was estimated using a purple seedling marker in 'Dark Opal' $(O$. basilicum). There were two patterns of outcrossing: 'Picollo' and four sources of 'Cinnamon' basil had outcrossing rates between $19.9 \%$ and $32.8 \%$, while 'Lemon', PI 368699, PI 174284, and a Purdue selection named 'Juicy Fruit' had outcrossing rates between $1.6 \%$ and 3.4\%.
\end{abstract}

Lamiaceae species are primarily crossbreeding and have a floral structure suitable for pollination by bees (Khosla, 1986). The most common pollinators of the genus Ocimum are honey bees (Apis mellifera L.) and cabbage butterflies [Pieris rapae (L.)] (Darrah, 1974). However, the genus Ocimum is also reported to contain self-pollinating species (Darrah, 1980; Torrey, 1989). Although Darrah (1974) reported a risk of cross-pollination contamination of basil cultivars grown in close proximity, outcrossing estimates were not presented. Natural outcrossing in 'French basil' ( 0 . basilicurn $2 n=48$ ) was estimated to be $66.7 \%$, using a purple-pigmented seedling marker controlled by two dominant genes, $R_{1}$ and $R_{2}$, in 'Kama Kasturi' (Krishnan, 1981). The present study was initiated to determine the percentage of natural outcrossing in nine accessions of basil as part of a breed-

Received for publication 30 Sept. 1991. Accepted for publication 15 July 1992. Journal Paper no. 13,163, Purdue Univ. Agr. Expt. Sta., West Lafayette, IN 47907. This research was supported by a grant to R.G.N. by the Herb Society of America (Mentor, Ohio) and by a grant from the Purdue Univ. Agr. Expt. Sta. (Specialty Crops Grant no. 014-1165-0000-65178). The cost of publishing this paper was defrayed in part by the payment of page charges. Under postal regulations, this paper therefore must be hereby marked advertisement solely to indicate this fact.

${ }^{1}$ To whom correspondence and reprint requests should be addressed. ing effort to obtain new essential oil chemotypes.

The dominance of purple over green leaf pigmentation was confirmed by selfs and reciprocal crosses of Burpee 'Sweet' basil and Burpee 'Dark Opal' basil. Selfed progeny of green or purple parental plants were either all green or all purple, respectively, but all $\mathrm{F}_{1}$ progeny were purple.

Nine accessions of basil (Table 1), all with green leaves, but varying widely in their morphology and aromatic properties, were grown in a checkerboard pattern alternating with 'Dark Opal' in Lafayette, Ind., in 1989. Each plot consisted of eight plants, four 'Dark Opal' plants and four plants of one of the nine accessions in two rows with spacing 0.7 $\mathrm{m}$ between rows and plants. The field plots were arranged in a randomized block design with three replications, and the entire experiment was surrounded by one border row consisting of alternating 'Dark Opal' plants and plants of the adjacent line being tested.

The indeterminate inflorescences were
Table 1. Outcross estimates in nine basil accessions interplanted with 'Dark Opal' basil.

\begin{tabular}{|c|c|c|c|c|c|c|c|}
\hline \multirow[b]{2}{*}{ Accession } & \multirow{2}{*}{$\begin{array}{c}\text { Seed } \\
\text { source }\end{array}$} & \multirow{2}{*}{$\begin{array}{c}\text { Relative } \\
\text { plant } \\
\text { size }\end{array}$} & \multirow{2}{*}{$\begin{array}{l}\text { Total } \\
\text { seedlings } \\
\text { scored } \\
\text { (no.) }\end{array}$} & \multicolumn{4}{|c|}{ Outcrossing $(\%)^{2}$} \\
\hline & & & & Early & Middle & Late & Total \\
\hline Picullox & Park Seed Co. & Medium & 812 & 17.6 & 27.0 & 61.0 & $32.8 \mathrm{a}^{\mathrm{w}}$ \\
\hline Cinnamon & Park & Large & 2897 & 23.2 & 30.1 & 36.8 & $30.0 \mathrm{a}$ \\
\hline Mexican Spicev & Peace Seed Co. & Large & 2954 & 21.8 & 31.0 & 24.9 & $25.8 \mathrm{a}$ \\
\hline Cinnamon & Burpee Seed Co. & Large & 4040 & 20.8 & 29.2 & 29.4 & $25.8 \mathrm{a}$ \\
\hline Cinnamon & Companion Plants & Large & 3222 & 22.9 & 18.0 & 18.7 & $19.9 \mathrm{a}$ \\
\hline PI 174284 & Turkey & Small & 5613 & 1.4 & 3.9 & 4.8 & $3.4 \mathrm{~b}$ \\
\hline PI 368699 & Yugoslavia & Medium & 5413 & 1.4 & 2.1 & 6.4 & $3.3 \mathrm{~b}$ \\
\hline Juicy Fruit & Purdue selection & Small & 4163 & 2.1 & 2.9 & 3.1 & $2.7 \mathrm{~b}$ \\
\hline Lemon & Burpee & Small & 1455 & 2.7 & 1.2 & 1.1 & $1.6 \mathrm{~b}$ \\
\hline \multirow{2}{*}{\multicolumn{2}{|c|}{$\begin{array}{l}\text { Total } \\
\text { Mean }\end{array}$}} & \multirow{2}{*}{\multicolumn{2}{|c|}{30,569}} & & & & \\
\hline & & & & 12.7 & 16.2 & 20.1 & \\
\hline \multirow{2}{*}{\multicolumn{2}{|c|}{ Analysis of variance }} & & \multirow{2}{*}{\multicolumn{2}{|c|}{ Mean square }} & \multirow{2}{*}{\multicolumn{2}{|c|}{ F value }} & \\
\hline & & $\mathrm{df}$ & & & & & $P$ value \\
\hline \multicolumn{2}{|l|}{ Accession } & 8 & \multicolumn{2}{|l|}{0.153} & \multicolumn{2}{|c|}{16.63} & 0.001 \\
\hline \multicolumn{2}{|c|}{ Replication (Rep.) } & 2 & \multicolumn{2}{|l|}{0.009} & \multicolumn{2}{|c|}{1.03} & 0.367 \\
\hline \multicolumn{2}{|c|}{ Rep. $\times$ accession } & 16 & \multicolumn{2}{|l|}{0.023} & \multicolumn{2}{|c|}{2.54} & 0.012 \\
\hline \multicolumn{2}{|c|}{ Inflorescence (infl.) section } & 2 & \multicolumn{2}{|l|}{0.014} & \multicolumn{2}{|c|}{1.57} & 0.223 \\
\hline \multicolumn{2}{|c|}{ Rep. $\times$ infl. section } & 4 & \multicolumn{2}{|c|}{0.018} & \multicolumn{2}{|c|}{1.98} & 0.121 \\
\hline \multicolumn{2}{|c|}{ Accession $\times$ infl. section } & 16 & \multicolumn{2}{|l|}{0.014} & \multicolumn{2}{|c|}{1.56} & 0.139 \\
\hline
\end{tabular}

${ }^{\mathrm{z}}$ Outcrossing based on $2 \times$ percent purple seedlings.

${ }^{y}$ 'Dark Opal' was classified as medium in size.

${ }^{\mathrm{x}}$ Small-leaved type of sweet basil.

${ }^{\text {w}}$ Means followed by different letters are significantly different at $P=0.05$, as determined by Duncan's multiple range test. Data were transformed by arcsin for analysis of variance, actual means presented. ${ }^{\mathrm{v}}$ Cinnamon type. 
collected at maturity and divided into thirds (bottom, middle, and top) representing the earliest, middle, and latest flowering portions, to determine whether the initial flowering date of each accession influenced outcrossing because flowering was not simultaneous among accessions. Seed from each plant was planted in the greenhouse and seedlings were scored when the color of the first true leaves was apparent. Because outcrossing could occur between either green $x$ green or green $\mathrm{x}$ purple plants, the mean percent outcrossing was calculated as twice the percentage of purple seedlings and transformed to arcsin for statistical analysis. This procedure assumes outcrossing rates are the same in green $\mathrm{x}$ green and green $\mathrm{x}$ purple crosses.

Differences in outcrossing were significant among the nine basil accessions (Table 1 ), but there were no significant differences for early, middle, and late flowering portions of the inflorescences evaluated across al accessions, nor was there a significant interaction between accession and inflorescence section. 'Picollo' basil, which most closely resembles a sweet or French basil type, had the highest percent outcrossing (32.8\%), less than Krishnan's (1981) report of $66.7 \%$ outcrossing for a cultivar of French basil. Outcrossing in the four methyl cinnamate chemotypes of basil (Park 'Cinnamon', Burpee 'Cinnamon', Peace 'Mexican Spice', and Companion Plants 'Cinnamon') did not significantly differ from 'Picollo' and ranged from $19.9 \%$ to $30.0 \%$. The four remaining basil lines (PI 174284, PI 368699, a Purdue selection named 'Juicy Fruit', and Burpee 'Lemon') had significantly lower outcrossing rates $(<4 \%)$. These accessions were morphologically more distinct from 'Dark Opal' than Park 'Picollo' or the 'Cinnamon' cultivars. PI 368699 bore flowers on a compact thyrse rather than on an elongate spike, typical of most Ocimum spp. PI 174284 and 'Lemon' had slightly smaller corollas (9.5 to $10 \mathrm{~mm}$ ) than the other accessions (11 to 12 $\mathrm{mm}$ ) and were less robust than the types that had higher outcrossing percentages. All accessions, except 'Juicy Fruit', were considered $O$. basilicum. Compared with the others, 'Juicy Fruit' was more pubescent, had a shorter calyx $(4 \mathrm{~mm})$ and corolla $(8 \mathrm{~mm})$ at maturity, with orange rather than creamy white pollen, and smaller seeds. We consider this selection to be $O$. kilimandscharicum (Murray, 1990) where $2 n=76$ (Sobti and Pushpangadan, 1982).

During the growing season, honey bees and cabbage butterflies were observed visiting flowers of all accessions indiscriminately; while it seems unlikely that insect preference for specific accessions contributed significantly to the different rates of outcrossing, this possibility remains. The low percentage of outcrossing in PI 174284, PI 368699, 'Juicy Fruit', and 'Lemon' may either be inherent in the floral mechanism or due to incompatability. Protandry might possibly reduce successful fertilization by foreign pollen. Although there was an equal number of plants of green and purple types, the num- ber of flowers varied but was not counted. Plant size of accessions with the low estimated outcrossing rates were smaller than the others.

Although the Lamiaceae is primarily outcrossing and the floral characters in $\mathrm{O}$. basilicum appear adapted to outcrossing via pollination by insects, the estimated rate of outcrossing varied between $19.9 \%$ and $32.8 \%$ for five accessions and between $1.0 \%$ and $3.5 \%$ for four accessions. Further studies will be needed to determine if the four accessions in which cross pollination was very low are naturally self-pollinated, as suggested for some species by Darrah (1980) and Torrey (1989), or due to incompatibility with 'Dark Opal'.

\section{Literature Cited}

Darrah, H.H. 1974. Investigations of the cultivars of basil (Ocimum). Econ. Bot. 28:63-67.
Darrah, H.H. 1980. The cultivated basils. Buckeye Printing, Independence, Mo.

Khosla, M.K. 1986. Inter-relationship studies of different species of the genus Ocimum. J. Plant Anatomy Morphol. 3:157-167.

Krishnan, R. 1981. Natural outcrossing in sweet basil, Ocimum basilicum L. Ind. Perfumer 25(3/ 4):74-77.

Murray, R.G. 1990. The potential of breeding Ocimum basilicum L. for essential oil content and composition. MS Thesis, Purdue Univ., West Lafayette, Ind.

Sobti, S.N. and P. Pushpangadan. 1982. Studies in the genus Ocimum: Cytogenetics, breeding and production of new strains of economic importance. p. 465. In: C.K. Atal and B.M. Kapur (eds). Cultivation and utilization of aromatic plants. Regional Res. Lab., Jammu-Tawi, India.

Torrey, T. 1989. Breeding herbs for culinary and ornamental use, p. 38-40. In: J.E. Simon, A. Kestner. and M.A. Buehrle (eds.). Proc. 4th Natl. Herb Growing and Marketing Conf., 2225 July 1989, San Jose, Calif 
Table 1. Effect of kinetin and BA on in vitro shoot count and length of Lupinus ferensis after 4 weeks.

\begin{tabular}{|c|c|c|c|}
\hline $\begin{array}{l}\text { Growth } \\
\text { regulator }\end{array}$ & $\begin{array}{l}\text { Concn } \\
(\mu \mathrm{M})\end{array}$ & $\begin{array}{l}\text { Mean shoot } \\
\text { no./explant }\end{array}$ & $\begin{array}{l}\text { Mean shoot } \\
\text { length (mm) }\end{array}$ \\
\hline \multicolumn{2}{|c|}{$\begin{array}{l}\text { Control (MS basal } \\
\text { medium) }\end{array}$} & $4.3 \pm 0.6^{2}$ & $60 \pm 2$ \\
\hline \multirow[t]{5}{*}{ Kinetin } & 0.5 & $4.5 \pm 0.5$ & $54 \pm 3$ \\
\hline & 4.6 & $10.8 \pm 0.7$ & $48 \pm 1$ \\
\hline & 13.3 & $8.6 \pm 0.9$ & $35 \pm 1$ \\
\hline & 23.2 & $7.2 \pm 1.2$ & $25 \pm 1$ \\
\hline & 46.0 & $6.2 \pm 0.8$ & $8 \pm 1$ \\
\hline \multirow[t]{5}{*}{$\mathrm{BA}$} & 0.4 & $9.5 \pm 1.2$ & $58 \pm 2$ \\
\hline & 4.4 & $15.0 \pm 0.5$ & $52 \pm 1$ \\
\hline & 13.9 & $13.4 \pm 1.1$ & $40 \pm 1$ \\
\hline & 22.2 & $9.0 \pm 1.1$ & $30 \pm 1$ \\
\hline & 44.0 & $9.7 \pm 0.8$ & $15 \pm 1$ \\
\hline
\end{tabular}

${ }^{z} \pm$ Values indicate SE of the mean $(n \geq 60)$ regression analyses indicated shoot count response to either kinetin or BA was cubic and significant at $P=0.05$; regression analysis indicated shoot length response to either kinetin or BA was quadratic and significant at $P=0.05$.

Table 2. Effect of NAA on in vitro rooting of tissue culture-derived shoots of Lupinus texensis. Data obtained 28 days after placement of 3-week-old shoots (developed on MS medium containing $4.4 \mu \mathrm{M} \mathrm{BA}$ ) in rooting medium.

\footnotetext{
${ }^{\mathrm{z}} \pm$ Values indicate SE of the mean.

${ }^{y} P=0.05$ determined by regression analysis.
}

Seeds were scarified in concentrated sulfuric acid for 35 to $40 \mathrm{~min}$ (Davis et al., 1991) and rinsed with distilled water. Following scarification, the seeds were dipped in $70 \%$ ethanol for $30 \mathrm{sec}$ and then rinsed four to five times with distilled water. Thereafter, the seeds were treated with $5.25 \%$ sodium hypochlorite for $15 \mathrm{~min}$ and $0.2 \% \mathrm{HgCl}_{2}$ for $5 \mathrm{~min}$. After being rinsed with sterile distilled water, seeds were placed on basal MS medium adjusted to $\mathrm{pH} 5.8$ (Murashige and Skoog, 1962). Seedlings were cultured in cylindrical glass culture vessels $(50-\mathrm{ml}$ capacity) at $25 \pm 1 \mathrm{C}$ under a 16 -h photoperiod and a photosynthetic photon flux of 40 to 50 $\mu \mathrm{mol} \cdot \mathrm{m}^{-2} \cdot \mathrm{s}^{-1}$ provided by cool-white fluorescent lamps. All subsequent experiments were conducted under these conditions.

Explants containing the cotyledonary node (10 $\pm 1 \mathrm{~mm}$ long with cotyledons removed) from 8- to 12-day-old seedlings (first true leaf just becoming visible at the apex) were placed on MS medium supplemented with various concentrations of kinetin or BA. One explant was used per culture vessel. The number of shoots per culture and shoot lengths were determined after 4 weeks. For the rooting experiments, 3- to 4-week-old microshoots $(50 \pm 5 \mathrm{~mm}$ long $)$ that developed on the medium containing $4.4 \mu \mathrm{M}$ BA were placed on basal MS medium supplemented with various concentrations of IAA, IBA, or NAA. The percentage of microcuttings exhibiting adventitious roots and the number of roots per culture were determined after 28 days. There was a minimum of 20 cultures per treatment and each experiment was repeated at least three times.

Kinetin $(\geq 4.6 \mu \mathrm{M})$ and BA (at all concentrations used) increased the number of shoots formed at the cotyledonary node ( $\mathrm{Ta}-$ ble 1). For both cytokinins, shoot formation was greatest at $\approx 4.5 \mu \mathrm{M}$. With $\mathrm{BA}$, this concentration resulted in $\approx 15$ shoots per explant after 4 weeks. With kinetin or BA $>4.5$ $\mu \mathrm{M}$, shoot formation declined but was still higher than in the control. Both cytokinins inhibited shoot growth, with severe stunting occurring at the higher concentrations.

Adventitious root formation was only observed on shoots placed in culture media containing NAA (Table 2). Both IAA and IBA, at concentrations ranging from 5 to 54 $\mu \mathrm{M}$, failed to induce rooting (data not shown). The highest rooting percentage $(14 \%)$ and the most roots (24) were produced in the medium containing $27 \mu \mathrm{M}$ NAA. Compared with most other herbaceous species, $L$. texensis appears to be difficult to root. Adventitious root formation has been observed from apical stem cuttings of $L$. albus and L. hartwegii (Ball, 1946; Lee, 1955), but Sator (1985) had little success in rooting in vitro- regenerated shoots of $L$. hartwegii and $\boldsymbol{L}$. luteus.

The results of this study indicate that shoot formation from cotyledonary node explants of $L$. texensis occurs readily on MS medium supplemented with cytokinins. Adventitious root formation on the microshoots, however, occurs only in the presence of relatively high concentrations of NAA and even then only at low frequency. About half of our rooted plantlets survived transfer to ex vitro conditions. More research is needed to overcome the recalcitrant nature of $L$. texensis shoots with regard to rooting and to improve acclimatization so that a higher frequency of plantlet regeneration can be achieved.

\section{Literature Cited}

Andrews, J. 1986. The Texas bluebonnet. Univ. Texas Press, Austin.

Ball, E. 1946. Development in sterile culture of stem tips and subjacent regions of Tropaeolum majus L. and Lupinus albus L. Amer. J. Bot. 33:301-318.

Chee, P.P., K.A. Fober, and J.L. Slightom. 1989. Transformation of soybean (Glycine max) by infecting germinating seeds with Agrobacterium tumefaciens. Plant Physiol. 91:1212-1218.

Davis, T.D., S.W. George, A. Upadhyaya, and J. Parsons. 1991. Improvement of seedling emergence in Lupinus texensis Hook. following seed scarification treatments. J. Environ. Hort. 9:17-21.

Jackson, J.A. and S.L.A. Hobbs. 1990. Rapid shoot production from cotyledonary node explants of pea. In Vitro Cell Dev. Biol. 26:835838.

Lee, A.E. 1955. Growth in culture of excised portion of lupin embryos. Bot. Gaz. 116: 354-364.

Mol, J.N.M., A.R. Stuitje, A. Gerats, A.R. van der Krol, and R. Jorgenson. 1989. Saying it with genes! Molecular flower breeding. Trends Biotechnol. 7:148-153.

Murashige, T. and F. Skoog. 1962. A revised medium for rapid growth and bioassays with tobacco tissue cultures. Physiol. Plant. 15:473497.

Sator, C. 1985. Studies on shoot regeneration of lupins (Lupinus spp.) Plant Cell Rptr. 4:126128.

van der Krol, A.R., L.A. Mur, P.D. Lange, J.N.M. Mol, and A.R. Stuitje. 1990. Inhibition of flower pigmentation by antisense CHS gene: Promoter and minimal sequence requirement for antisense effect. Plant Mol. Biol. 14:457-466. 